Potravinarstvo Slovak Journal of Food Sciences vol. 13, 2019, no. 1, p. 174-181

doi: https://doi.org/10.5219/1047

Received: 9 February 2019. Accepted: 28 March 2019.

Available online: 25 March 2019 at www.potravinarstvo.com

(C) 2019 Potravinarstvo Slovak Journal of Food Sciences, License: CC BY 3.0

ISSN 1337-0960 (online)

\title{
MICROBIOTA OF DIFFERENT WINE GRAPE BERRIES
}

\author{
Miroslava Kačániová, Simona Kunová, Soňa Felsöciová, Eva Ivanišová, Attila Kántor, \\ Jana Žiarovská, Czeslaw Puchalski, Margarita Terentjeva
}

\begin{abstract}
The wine grape berries share a complex microbial ecology including filamentous fungi, yeasts and bacteria. The microbiota reveals different physiological characteristics and depends on the grape ripening stage and the availability of nutrients with different effect on wine production. The microbiota of grape berries $(n=12)$ was isolated and identified in the present study. The samples were collected in September 2018. Grape berries were obtained from Vrbovo vineyard located in Slovakia. The grape berries investigated belonged to Blue Frankish, Cabernet Sauvignon, Chardonnay, Dornfelder, Feteasca regala, Green Veltliner, Irsai Oliver, Mūller Thurgau, Pálava, Pinot Blanc, Rhinriesling and Welschriesling varieties. The microorganisms were cultivated on Malt extract agar (MEA) at $25{ }^{\circ} \mathrm{C}$ for five days in aerobically for microscopic filamentous fungi and Tryptone Soya agar (TSA) at $37^{\circ} \mathrm{C}$ for $24-48 \mathrm{~h}$ aerobically for bacteria and yeasts. Total bacterial counts on different wine grape berries ranged from $2.57 \pm 0.09$ in Chardonnay to $4.39 \pm 0.21 \mathrm{log}$ CFU.g ${ }^{-1}$ in Pálava. Microscopic filamentous fungi count ranged from $1.18 \pm 0.03$ in Blue Frankish to $2.60 \pm 0.17 \log$ CFU.g ${ }^{-1}$ in Welschriesling. MALDI-TOF MS Biotyper mass spectrometry was used for identification of microorganisms (bacteria and yeasts) and microscopic filamentous fungi with manuals. The most identified microscopic fungal species was Alternaria sp., for yeasts Issatchenkia orientalis and Leuconostoc mesenteroides subsp. mesenteroides for bacteria.
\end{abstract}

Keywords: microbiota; grape berries; identification; MALDI-TOF MS Biotyper

\section{INTRODUCTION}

The $V$. vinifera phyllosphere is colonized by bacteria and fungi which modulate health, development and quality of grape and the produced wine characteristics (Barata, Malfeito-Ferreira andLoureiro, 2012). The grape surface inhabiting microorganisms are sensitive to environmental changes during wine fermentation and cannot survive in low $\mathrm{pH}$, ethanolic and anaerobic conditions. At the same their metabolic activity on the grape surface can have consequences for wine quality, e.g. metabolic changes produced by phytopathogenic fungi (Hong et al., 2011).

The grape microbiota more often demonstrates the beneficial effect, and the participation of microbiota in wine fermentations can improve the sensory characteristics of wines (Ciani et al., 2010). Studies of microbiota involved in wine fermentations allowed a discovery of microbial species, which show positive enological properties. The application of those microorganisms with Saccharomyces yeasts was commercialized in winemaking (Ciani et al., 2010). With improvement of detection and identification methods in winemaking, a growing number of microorganisms were recognized as active contributors in wine fermentations with significant improvement of sensory qualities of wine (Ciani et al., 2010).

Regional wines characteristics potentially are influenced by microbial biogeography, which is another important factor for winemaking. Traditional winemaking relies mostly on native grape microbiota for fermentations. This practice thought to enhance the regional typicity. The role of microorganisms is well described for grape health, fruit and wine quality (Barata, Malfeito-Ferreira and Loureiro, 2012), but the effect of grape microbiota on regional characteristics of wines is still of limited knowledge. The effect of geographic region, grape variety, and climatic factors influence the bacterial and fungal communities of wine grapes was shown through the growing years (Bokulich et al., 2014). The regional fungal biodiversity of grapes was demonstrated also globally (Taylor et al., 2014; Gayevskiy and Goddard, 2012; Pinto et al., 2015). The local Saccharomyces cerevisiae strains, the principal yeast species for wine fermentations purposes, resulting in distinct wine chemical compositions, thus the role of regional microbiota is important for winemaking (Knight et al., 2015).

Study of microbiota of grape berries was conducted in Slovakia (Kačániová et al., 2018). A total of 33 species of 8 Gram-negative $\left(\mathrm{G}^{-}, 20.72 \%\right)$ and 10 Gram-positive $\left(\mathrm{G}^{+}\right.$, $31.53 \%$ ) bacteria and 10 yeasts species of 8 genera $(47.74 \%)$ were identified with MALDI-TOF Mass Spectrometry. These results show that the yeasts were the most common group pf microorganisms isolated from grapes, but the yeasts and bacteria were isolated from each 
grape variety. Bacteria counts were higher than yeast. The highest counts of yeast species were identified in Irsai Oliver (10.06\%), Pálava, Pinot Blanc and Rheinriesling (9.43\%) grape varieties (Kačániová et al., 2018).

\section{Scientific hypothesis}

Grape berries contain bacteria, yeasts and moulds, which could be identified with MALDI-TOF mass spectrometry. Microbial ecology of grapes could affect the wine grape berries health. Accurate identification of wine grape berries microbiota is essential to understand the grape microbial ecology.

\section{MATERIAL AND METHODOLOGY}

\section{Wine grape berry samples}

Twelve grape samples from wineyard in Vrbové located in the Small Carpathian wine region were used in this experiment. Ripe grape bunches were collected into sterile polyethylene bags and transported to the laboratory for microbiological analyses. The grape samples of following varieties were investigated: Blue Frankish, Cabernet Sauvignon, Chardonnay, Dornfelder, Feteasca regala, Green Veltliner, Irsai Oliver, Mūller Thurgau, Pálava, Pinot Blanc, Rhinriesling and Welschriesling.

\section{Microbiological analyses of grape berries samples \\ Five grams of grape berries from each variety were diluted with $45 \mathrm{~mL}$ of sterile physiological saline $(0.85 \%)$. Berries were stirred on a horizontal shaker for $30 \mathrm{~min}$. After that, the dilutions of $10^{-2}$ and $10^{-3}$ were prepared for cultivation of sampled with spread plate method. A $0.1 \mathrm{~mL}$ of each dilution $\left(10^{-2}, 10^{-3}\right)$ was cultivated on Plate count agar (PCA) (Oxoid, UK) and on Malt extract agar base (MEA) (Oxoid, UK) supplemented with bromocresol green (0.020 g. $\left.\mathrm{L}^{-1}\right)$ (Centralchem ${ }^{\circledR}$, Slovakia). Inoculated PCA agars were cultivated at $37{ }^{\circ} \mathrm{C}$ for $24-48 \mathrm{~h}$ aerobically. Microscopic filamentous fungi were cultivated at $25^{\circ} \mathrm{C}$ for five days aerobically. The identification of fungal species was done according to the manuals of Samson et al. (2002), Samson and Frisvad (2004), Pitt and Hocking (2009). \\ Growing colonies with macroscopic morphological differences were recultivated on TSA (Tryptic Soya agar, Oxoid $\left(\right.$ ) and inoculated plates were cultivated at $30{ }^{\circ} \mathrm{C}$ or $25{ }^{\circ} \mathrm{C}$ for $24 \mathrm{~h}$ for bacteria and yeasts, respectively. After cultivation, the proteins were extraction was done.}

\section{Sample preparation and MALDI-TOF MS measurement}

One colony of each bacterial and yeast isolate was transferred into an Eppendorf vial and mixed with $300 \mu \mathrm{L}$ of sterile water. After addition of ethanol $(900 \mu \mathrm{L})$, the suspension was mixed and centrifuged (13 $000 \mathrm{~g}, 2 \mathrm{~min})$. After removal of supernatant, the pellets were dried at room temperature at least for $5 \mathrm{~min}$. The bacterial and yeast pellets were resuspended in $20-50 \mu \mathrm{l}$ of formic acid (70\%) and the same amount of acetonitrile. After centrifugation ( $2 \mathrm{~min}$ at $13000 \mathrm{~g}$ ), a $1 \mu \mathrm{L}$ of supernatant was spotted onto a sample position of a polished steel MALDI target plate and dried at room temperature. A $1 \mu \mathrm{L}$ of MALDI matrix (solution of $\alpha$-cyano-4-hydroxycinnamic acid (HCCA) in $50 \%$ acetonitrile / $2.5 \%$ trifluoro-acetic acid) was added to the spot and dried.
The MALDI target plate was introduced into the MALDITOF mass spectrometer for automated measurement and data interpretation. MALDI-TOF profile mass spectra were imported into the MALDI Biotyper 3.0 software and processed automatically after measurement. The logarithm of the score (log[score]) was displayed as the matching result. The MALDI Biotyper output was a $\log$ (score) between 0 and 3.0, which was calculated from a comparison of the peak list from an unknown isolate with the reference MSP in the database. A $\log$ (score) $\geq 1.7$ indicated identification at the genus level, $\log$ (score) $\geq 2.0$ was set as the threshold for a match at the species level. Isolates with $\geq 2.0$ were accepted as a correct identification (Kačániová et al., 2018).

Climatic conditions during the wine grape harvest

Climatic conditions during the harvest were characterized by air temperature (Figure 1), soil temperature (Figure 2), and cumulative rainfall (Figure 3 ).

\section{Statistic analysis}

All experiments were carried out in triplicate and standard deviations for replication were calculated. The experimental data were subjected to analysis of variance (Duncan's test) at a 95\% confidence level (software XL STAT, 2019).

\section{RESULTS AND DISCUSSION}

In our study, the total bacteria counts isolated from different wine grape berries ranged from $2.57 \pm 0.09$ in Chardonnay to $4.39 \pm 0.21 \log$ cfu. $^{-1}$ in Pálava (Table 1). Microscopic filamentous fungi count ranged from 1.18 \pm 0.03 in Blue Frankish to $2.60 \pm 0.17 \mathrm{log}$ cfu.g $^{-1}$ in Welschriesling. Kántor et al. (2015) found the bacteria counts on Acetobacter agar (AA) from 1.76 to $2.80 \log$ cfu. $\mathrm{mL}^{-1}$. The highest counts of acetic acid bacteria on AA agar was found in grape variety Blaufränkisch (2.80 log cfu. $\mathrm{mL}^{-1}$ ). Lactic acid bacteria (LAB) counts on MRS agar ranged from 0.48 to $2.06 \log$ cfu. $\mathrm{mL}^{-1}$, but the LAB was not isolated from white grape varieties.

Table 1 Microorganisms counts isolated from wine grape berry varieties in $\log$ cfu.g $\mathrm{g}^{-1}$.

\begin{tabular}{lcc}
\hline Grape type & TSA & MEA \\
\hline Blue Frankish & $4.42 \pm 0.16^{\mathrm{a}}$ & $1.18 \pm 0.03^{\mathrm{c}}$ \\
Cabernet Savignon & $4.42 \pm 0.09^{\mathrm{a}}$ & $2.51 \pm 0.09^{\mathrm{ab}}$ \\
Chardonnay & $2.57 \pm 0.09^{\mathrm{d}}$ & $2.35 \pm 0.16^{\mathrm{b}}$ \\
Dornfelder & $3.77 \pm 0.12^{\mathrm{b}}$ & $1.25 \pm 0.06^{\mathrm{c}}$ \\
Feteasca regala & $3.75 \pm 0.07^{\mathrm{b}}$ & $2.44 \pm 0.11^{\mathrm{ab}}$ \\
Green Veltliner & $3.43 \pm 0.20^{\mathrm{c}}$ & $2.35 \pm 0.17^{\mathrm{b}}$ \\
Irsai Oliver & $3.85 \pm 0.09^{\mathrm{b}}$ & $2.37 \pm 0.14^{\mathrm{ab}}$ \\
Mūller Thurgau & $3.55 \pm 0.07^{\mathrm{bc}}$ & $2.49 \pm 0.06^{\mathrm{ab}}$ \\
Pálava & $4.39 \pm 0.21^{\mathrm{a}}$ & $1.18 \pm 0.04^{\mathrm{c}}$ \\
Pinot Blanc & $3.64 \pm 0.13^{\mathrm{bc}}$ & $2.44 \pm 0.15^{\mathrm{ab}}$ \\
Rhinriesling & $3.78 \pm 0.19^{\mathrm{b}}$ & $2.43 \pm 0.08^{\mathrm{ab}}$ \\
Welschriesling & $3.41 \pm 0.16^{\mathrm{c}}$ & $2.60 \pm 0.17^{\mathrm{a}}$ \\
\hline
\end{tabular}

Note: TSA-Tryptic Soya agar, MEA-Malt extract agar; mean \pm standard deviation; different letters in column mean that values were significantlv different 


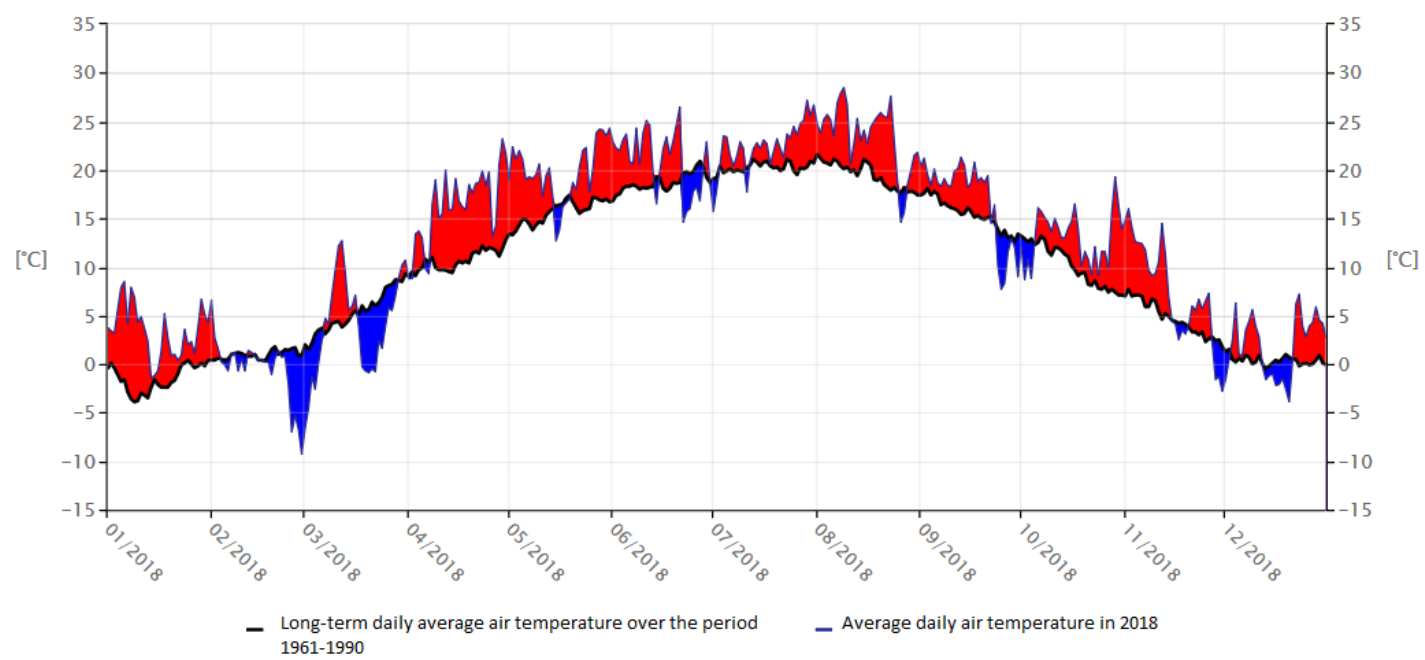

Figure 1 Average daily air temperature in Vrbové in 2018 (www.shmu.sk).

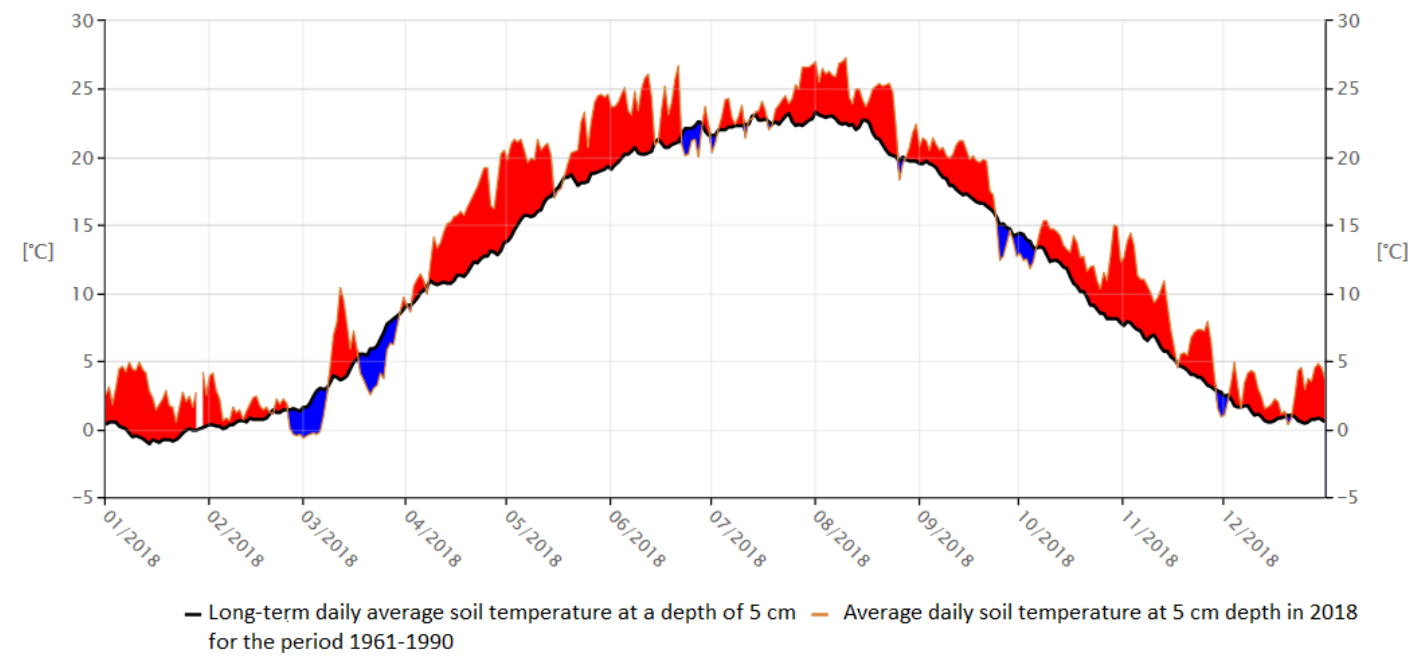

Figure 2 Average daily soil temperature in Vrbové in 2018 (www.shmu.sk).

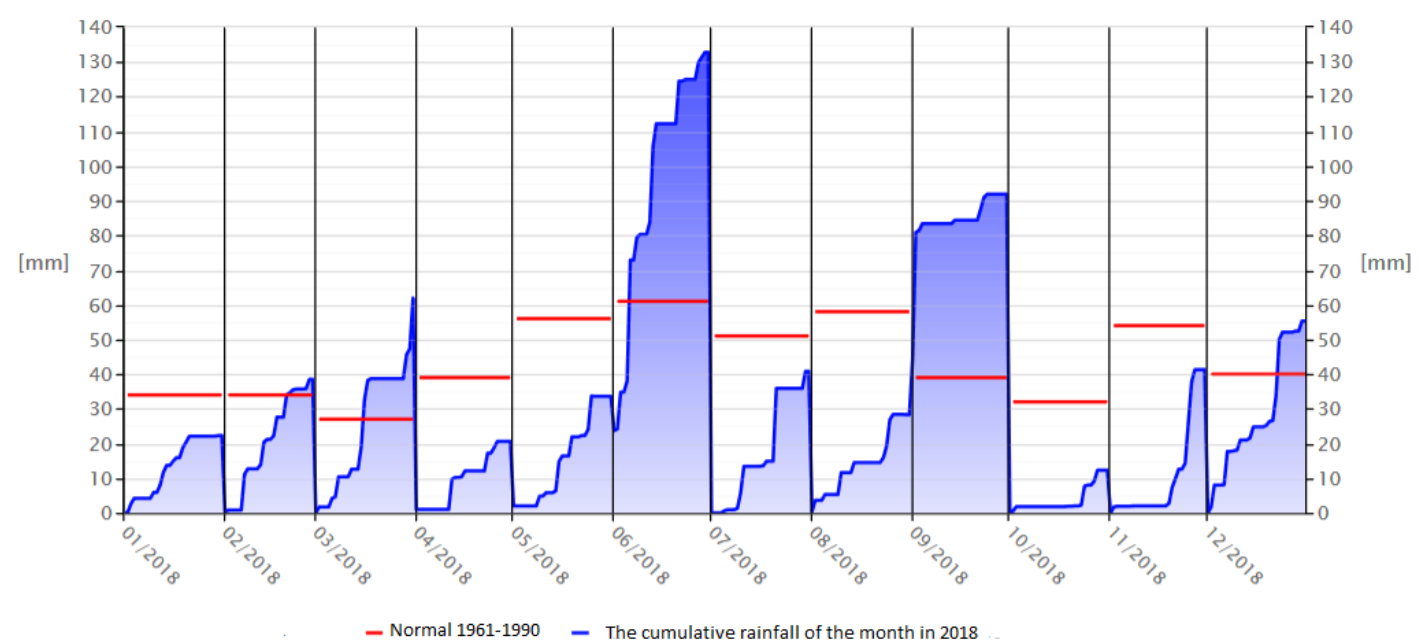

Figure 3 The cumulative rainfall in Vrbové in 2018 (www.shmu.sk). 


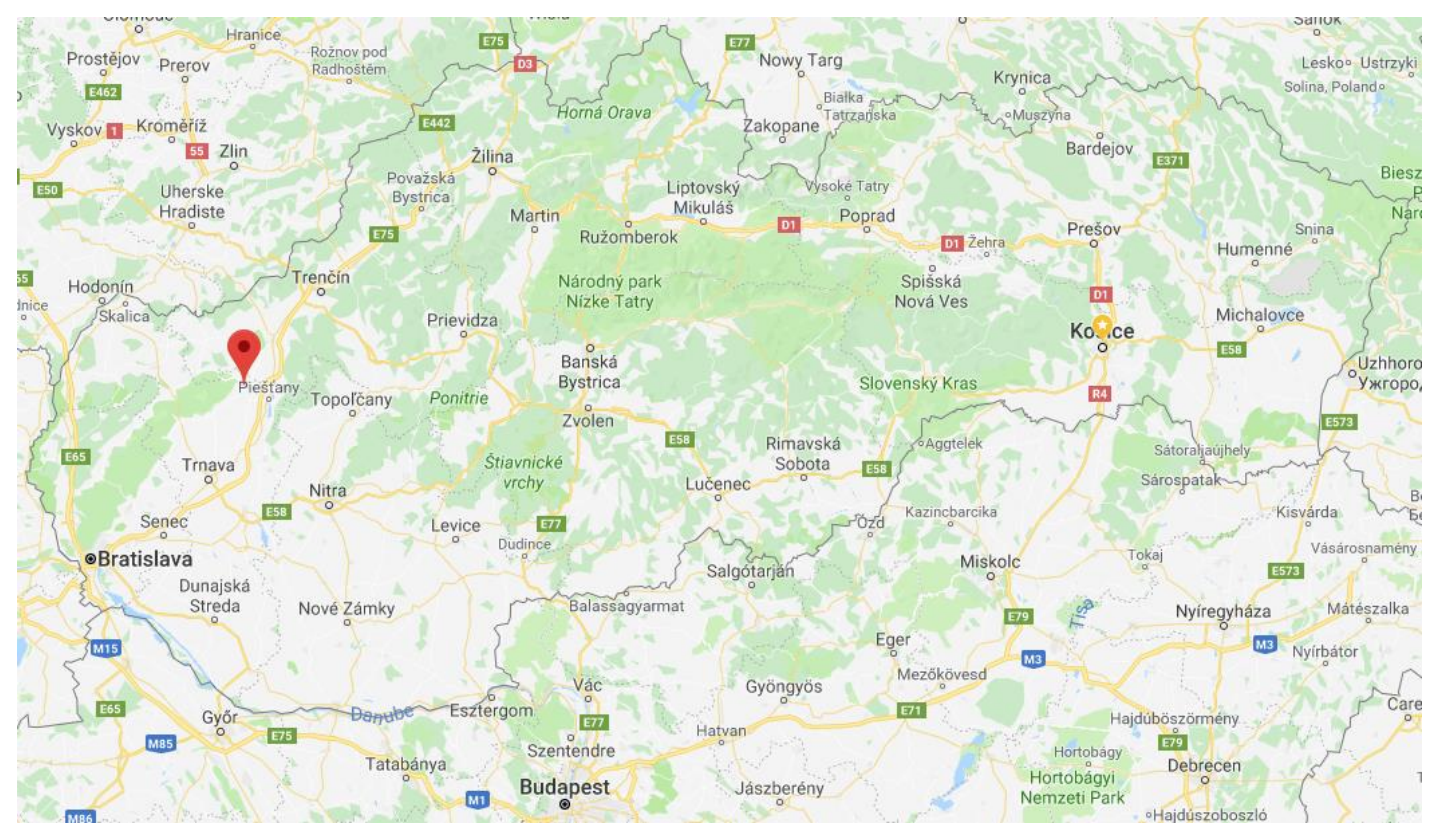

Figure 4 Vrbové, Slovakia - location.

Table 2 Microorganisms isolated from different wine grape berries varieties

\begin{tabular}{ll}
\hline Grape variety & \multicolumn{1}{c}{ Isolated microorganisms } \\
\hline \multirow{6}{*}{ Blue Frankish } & Alternaria sp., Arthrobacter koreensis, Bacillus cereus, Candida magnoliae, \\
& Escherichia coli, Hanseniaspora uvarum, Issatchenkia orientalis, Kazachstania \\
& exigua, Kluyveromyces marxianus, Lactobacillus acidophilus, Lactobacillus \\
& paracasei, Leuconostoc mesenteroides susp. mesenteroides, Pantoea agglomerans, \\
& Rhodotorula glutinis, Staphylococcus epidermidis, Stenotrophomonas maltophilia, \\
& Yarrowia lipolytica \\
\hline \multirow{5}{*}{ Cabernet Savignon } & Alternaria sp., Arthrobacter koreensis, Bacillus cereus, Botrytis cinerea, \\
& Cladosporium sp., Enterobacter cloacae, Hanseniaspora uvarum, Ignatzschineria \\
& indica, Issatchenkia orientalis, Kazachstania exigua, Lactobacillus acidophilus, \\
& Leuconostoc mesenteroides subsp. mesenteroides, Metschnikowia pulcherrima, \\
& Micrococcus luteus, Staphylococcus epidermidis, Stenotrophomonas maltophilia, \\
& Yarrowia lipolytica \\
\hline Chardonnay & Alternaria sp., Bacillus endophyticus, Escherichia coli, Hanseniaspora uvarum, \\
& Issatchenkia orientalis, Kazachstania exigua, Lactobacillus fermentum, Leuconostoc \\
& mesenteroides subsp. mesenteroides, Metschnikowia pulcherrima, Pantoea \\
& agglomerans, Stenotrophomonas maltophilia, Yarrowia lipolytica \\
\hline Alternaria sp., Arthrobacter koreensis, Bacillus cereus, Hanseniaspora uvarum, \\
Ignatzschineria indica, Issatchenkia orientalis, Lactobacillus fermentum, \\
Lactobacillus paracasei, Leuconostoc mesenteroides susp. mesenteroides, Pantoea \\
agglomerans, Rhodotorula glutinis, Yarrowia lipolytica \\
\hline
\end{tabular}


Table 2 Microorganisms isolated from different wine grape berries varieties (continue)

\begin{tabular}{|c|c|}
\hline Grape variety & Isolated microorganisms \\
\hline Feteasca regala & $\begin{array}{l}\text { Bacillus endophyticus, Candida magnoliae, Escherichiacoli, Hanseniaspora uvarum, } \\
\text { Kazachstania exigua, Lactobacillus fermentum, Lactobacillus paracasei, } \\
\text { Leuconostoc mesenteroides subsp. mesenteroides, Micrococcus luteus, Penicillium } \\
\text { expansum, Staphylococcus epidermidis }\end{array}$ \\
\hline Green Veltliner & $\begin{array}{l}\text { Alternaria sp., Bacillus cereus, Hanseniaspora uvarum, Issatchenkia orientalis, } \\
\text { Lactobacillus fermentum, Lactobacillus paracasei, Leuconostoc mesenteroides subsp. } \\
\text { mesenteroides, Metschnikowia pulcherrima, Pantoea agglomerans, } \\
\text { Stenotrophomonas maltophilia, Yarrowia lipolytica }\end{array}$ \\
\hline Irsai Oliver & $\begin{array}{l}\text { Bacillus endophyticus, Cladosporium sp., Hanseniaspora uvarum, Issatchenkia } \\
\text { orientalis, Kazachstania exigua, Kluyveromyces marxianus, Lactobacillus } \\
\text { fermentum, Lactobacillus paracasei, Leuconostoc mesenteroides subsp. } \\
\text { mesenteroides, Metschnikowia pulcherrima, Penicillium expansum, Rhodotorula } \\
\text { glutinis, Staphylococcus epidermidis }\end{array}$ \\
\hline Mūller Thurgau & $\begin{array}{l}\text { Bacillus cereus, Cladosporium sp., Hanseniaspora uvarum, Ignatzschineria indica, } \\
\text { Issatchenkia orientalis, Kazachstania exigua, Kluyveromyces marxianus, } \\
\text { Lactobacillus paracasei, Leuconostoc mesenteroides subsp. mesenteroides, } \\
\text { Metschnikowia pulcherrima, Micrococcus luteus, Penicillium expansum, } \\
\text { Stenotrophomonas maltophilia }\end{array}$ \\
\hline Pálava & $\begin{array}{l}\text { Aeromonas hydrophila, Alternaria sp., Aspergillus niger, Cladosporium sp., } \\
\text { Hanseniaspora uvarum, Issatchenkia orientalis, Lactobacillus fermentum, } \\
\text { Lactobacillus paracasei, Metschnikowia pulcherrima, Pantoea agglomerans, } \\
\text { Staphylococcus epidermidis, Stenotrophomonas maltophilia, Yarrowia lipolytica, }\end{array}$ \\
\hline Pinot Blanc & $\begin{array}{l}\text { Bacillus endophyticus, Botrytis cinerea, Cladosporium sp., Hanseniaspora uvarum, } \\
\text { Ignatzschineria indica, Kazachstania exigua, Kluyveromyces marxianus, } \\
\text { Lactobacillus paracasei, Leuconostoc mesenteroides susp. mesenteroides, } \\
\text { Metschnikowia pulcherrima, Penicillium expansum, Stenotrophomonas maltophilia }\end{array}$ \\
\hline Rhinriesling & $\begin{array}{l}\text { Alternaria sp., Bacillus endophyticus, Hanseniaspora uvarum, Issatchenkia } \\
\text { orientalis, Lactobacillus fermentum, Lactobacillus paracasei, Metschnikowia } \\
\text { pulcherrima, Pantoea agglomerans, Penicillium expansum, Rhodotorula glutinis, } \\
\text { Staphylococcus epidermidis, Stenotrophomonas maltophilia }\end{array}$ \\
\hline Welschriesling & $\begin{array}{l}\text { Alternaria sp., Bacillus licheniformis, Candida magnoliae, Hanseniaspora uvarum, } \\
\text { Issatchenkia orientalis, Kazachstania exigua, Lactobacillusfermentum, Lactobacillus } \\
\text { paracasei, Leuconostoc mesenteroides susp. mesenteroides, Metschnikowia } \\
\text { pulcherrima, Staphylococcus epidermidis, Stenotrophomonas maltophilia }\end{array}$ \\
\hline
\end{tabular}

The highest LAB counts were found in grape variety Cabernet sauvignon of $2.06 \log$ cfu.mL $\mathrm{m}^{-1}$, and the highest counts of LAB were detected in Blaufränkisch grape variety. The yeasts count on Sabouraud dextrose agar (SDA) ranged from $2.47 \log$ cfu.mL $L^{-1}$ to $2.76 \log$ cfu.mL $L^{-1}$, and the highest counts were on Blaufränkisch grape variety surface. In generally, limited yeast diversity and low bacteria counts $\left(10-10^{3}\right.$ CFU.mL $\left.{ }^{-1}\right)$ were detected on immature grape berries, but the yeasts count increased to $10^{4}-10^{6}$ CFU.mL $L^{-1}$ as the grapes were ripe enough to harvest. During ripening, the sugars diffuse from the inner tissues of the grape to the surface, that facilitating yeast 
growth. Unripe grapes mostly harbour Rhodotorula, Cryptococcus and Candida species. These species could be isolated from mature, ripe grapes, however, the apiculate yeasts as Hanseniaspora (anamorph Kloeckera) and Metschnikowia, were mostly distributed. Hanseniaspora (Kloeckera), Candida and Metschnikowia species, as well as species of Saccharomyces and Zygosaccharomyces has increased incidence on the damaged grapes (Fleet, 2003).

In our samples, different bacterial, yeasts and fungal species were found (Table 2). The most abundant microscopic filemanous fungi were: Alternaria sp., Aspergillus niger, Botrytis cnerea, Cladosporium sp. and Penicillium expansum. Alternaria sp. was found in 8 $(66.7 \%)$ wine grape berries samples. Altogether nine yeast species were isolated: Candida magnoliae, Hanseniospora uvarum, Ignatzschineria indica, Issatchenkia orientalis, Kazachstania exigua, Kluyveromyces marxianus, Metschnikowia pulcherrima, Rhodotorula glutinis and Yarrowia lipolityca. Issatchenkia orientalis was the most abundant yeast, which was found in 10 grapes varieties $(83.33 \%)$. In total, 14 bacterial species were isolated: Arthrobacter koreeniss, Bacillus endophyticus, B. cereus, B. licheniformis, Escherichia coli, Enterobacter cloacae, Lactobacillus acidophilus, L. paracasei, L. feremntum, Leuconostoc mesenteroides subs. mesenteroides, Micrococcus luteus, Pantotea agglomerans, Staphylococcus epidermidis and Stenotrophomonas maltophilia. The most distributed bacterial species was Leuconostoc mesenteroides subs. mesenteroides, which was isolated from 10 grape berry varieties $(83.33 \%)$.

The microorganisms can contaminate from different environmental sources. The origin of microorganisms could be the vineyard, can be residents of the winery flora, or can be transmitted with insects such as fruit flies and, bees (Fleet et al., 2002). Over twenty yeast species have been identified in wines (Renouf et al., 2007). Hanseniaspora uvarum (anamorph: Kloeckera apiculata), Metschnikowia pulcherrima (anamorph: Candida pulcherrima), and Candida stellata are thought to be the principal yeasts of grapes. In some studies, Hanseniaspora was reported to be the dominant species (Beltran et al., 2002; Combina et al., 2005; Hierro et al., 2006), while Candida assumed to be widespread as well (Clemente-Jimenez et al., 2004). Majority of Candida stellata isolates from wine are actually Candida zemplinina (Csoma and Sipiczki, 2008).

Kačániová et al. (2018) isolated from the surface of grape berries different species of microorganisms. The most abundant $\mathrm{G}^{-}$bacteria were Stenotrophomonas maltophilia and Ignatzschineria indica. Same results were found in the present study with wine grape berries. Within 22 different species of $\mathrm{G}^{+}$bacteria, Bacillus endophyticus, Paenibacillus glucanolyticus, Paenibacillus lautus and Staphylococcus succinus were the most isolated among bacteria Rhodotorula mucilaginosa was the most abundant among yeasts.

Kunová et al. (2018) found fungal counts ranged from $2.85 \mathrm{log}$ cfu. $\mathrm{g}^{-1}$ in Cabernet Sauvignon to $4.83 \mathrm{log}_{\mathrm{cfu} . \mathrm{g}^{-1} \text { in }}$ Feteasca regala. After identification of 627 isolates of microscopic fungi, moulds belonged to genera Alternaria and Penicillium were the most widespread and were isolated from $100 \%$ of samples. Alternaria sp. was the most abundant fungal species in our study also. The high prevalence of Aspergillus (76.92\%) and Cladosporium (76.92\%) was found (Table 2).

Alternaria, Cladosporium and Penicillium were the most abundant moulds after identification of 1377 cultures of microscopic fungi isolates Felsöciová et al. (2017). The identified prevalence found was similar to our results (100\%). The higher prevalence was detected for Fusarium (100\%), Epicoccum, Rhizopus (87.5\%), Botrytis, Aspergillus (75\%) and Mucor (62.5\%). Different fungal genera with higher prevalence in comparison with our study were identified. Kántor et al. (2017) found 11 genera of $\mathrm{G}^{-}$ $(11 \%), 11$ of $\mathrm{G}^{+}(27 \%)$ bacteria and nine genera of yeasts $(62 \%)$ among 200 isolates of 19 Slovak grape samples. The most frequently isolated $\mathrm{G}^{-}$bacteria were Acinetobacter (22\%), Pseudomonas (22\%) and Sphingomonas (13\%). The most common genera of $\mathrm{G}^{+}$bacteria were Bacillus (20\%), Lactobacillus (19\%), Leuconostoc and Staphylococcus $(11 \%)$. The most common yeasts genera were Hanseniaspora (37\%), Metschnikowia (31\%), and Rhodotorula $(10 \%)$. Our results on diversity of microbial species in grape samples corresponded to Kántor et al. (2017) results.

Similar results were described in Kántor et al. (2016) study, who studied similar grape wine varieties as sampled in our study. The most dominant species was Saccharomyces cerevisiae isolated from all 15 new wine samples, that was a very good wine quality indicator. Altogether, seven different $S$. cerevisiae strains were identified with mass spectrometry, the second most common species was Kloeckera apiculata (Hanseniaspora uvarum) found in seven new wine samples. Also, other non - Saccharomyces yeasts such as Metschnikowia pulcherrima, Pichia occidentalis and Pichia kluyveri were identified.

\section{CONCLUSION}

Natural microflora of grape berries is very diverse. In our study, the bacteria were the most distributed in comparison with other groups of microorganisms. The highest bacterial counts were found in Palava grape variety, followed by Welschriesling. In our study, 5 different yeast, 9 moulds and 14 bacteria species on grape berries were identified.

\section{REFERENCES}

Barata, A., Malfeito-Ferreira, M., Loureiro, V. 2012. The microbial ecology of wine grape berries. International Journal of Food Microbiology, vol. 153, no. 3, p. 243-259. https://doi.org/10.1016/j.ijfoodmicro.2011.11.025

Beltran, G., Torija, M. J., Novo, M., Ferrer, N., Poblet, M., Guillamon, J. M., Rozes, N., Mas, A. 2002. Analysis of yeast populations during alcoholic fermentation: A six year followup study. Systematic and Applied Microbiology, vol. 25, p. 287-293. https://doi.org/10.1078/0723-2020-00097

Bokulich, N. A., Thorngate, J. H., Richardson, P. M., Mills, D. A. 2014. Microbial biogeography of wine grapes is conditioned by cultivar, vintage, and climate. Proceedings of the National Academy of Sciences United States of America, vol. 111, no. 1, p. E139-E148. https://doi.org/10.1073/pnas.1317377110

Ciani, M., Comitini, F., Mannazzu, I., Domizio, P. 2010. Controlled mixed culture fermentation: A new perspective on the use of non-Saccharomyces yeasts in winemaking. FEMS Yeast Research, vol. 10, no. 2, p. 123-133. https://doi.org/10.1111/j.1567-1364.2009.00579.x 
Clemente-Jimenez, J. $\quad$ M., Mingorance-Carzola, L., Martinez-Rodriguez, S., Las Heras-Vazquez, F. J., RodriguezVico, F. 2004. Molecular characterization and oenological properties of wine yeasts isolated during spontaneous fermentation of six varieties of grape must. Food Microbiology, vol. 21, p. 149-155. https://doi.org/10.1016/s0740-0020(03)00063-7

Combina, M., Mercado, L., Borgo, P., Elia, A., Joofre, V., Ganga, A., Martinez, C., Catania, C. 2005. Yeasts associated to Malbec grape berries from Mendoza, Argentina. Journal of Applied Microbiology, vol. 98, no. 5, p. 1055-1061. https://doi.org/10.1111/j.1365-2672.2005.02540.x

Csoma, H., Sipiczki, M. 2008. Taxonomic reclassification of Candida stellata strains reveals frequent occurrence of Candida zemplinina in wine fermentation. FEMS Yeast Research, vol. 8, p. 328-336. https://doi.org/10.1111/j.15671364.2007.00339.x

Felsöciová, S., Tančinová, D., Rybárik, L., Mašková, Z. 2017. Mycobiota of Slovak wine grapes with emphasis on Aspergillus and Penicillium species in the south slovak wine region. Potravinarstvo Slovak Journal of Food Sciences, vol. 11, no. 1, p. 496-502. https://doi.org/10.5219/789

Fleet, G. H. 1990. Growth of yeasts during wine fermentations. Journal of Wine Research, vol. 1, p. 211-223. https://doi.org/10.1080/09571269008717877

Fleet, G. H. 2003. Yeast interactions and wine flavour. International Journal of Food Microbiology, vol. 86, no. 1-2, p. 11-22. https://doi.org/10.1016/s0168-1605(03)00245-9

Fleet, G. H., Prakitchaiwattana, C. J., Beh, A. L., Heard, G. M. 2002. The yeast ecology of wine grapes. In Ciani, M. Biodiversity and Biotechnology of Wine Yeasts. Kerala, India : Research Signpost, p. 1-17. ISBN 13: 9788177361209.

Gayevskiy, V., Goddard, M. R. 2012. Geographic delineations of yeast communities and populations associated with vines and wines in New Zealand. International Society for Microbial Ecoligy Journal, vol. 6, p. 1281-1290. https://doi.org/10.1038/ismej.2011.195

Hierro, N., Gonzales, A., Mas, A., Guillamon, J. M. 2006. Diversity and evolution of non-Saccharomyces yeast populations during wine fermentation: effect of grape ripeness and cold maceration. FEMS Yeast Research, vol. 6, p. 102-111. https://doi.org/10.1111/j.1567-1364.2005.00014.X

Hong, Y. S., Cilindre, C., Liger-Belair, G., Jeandet, P., Hertkorn, N., Schmitt-Kopplin, P. 2011. Metabolic influence of Botrytis cinerea infection in champagne base wine. Journal of Agriculture and Food Chemistry, vol. 59, no. 13, p. 72377245. https://doi.org/10.1021/jf200664t

Kačániová, M., Terentjeva, M., Felsöciová, S., Ivanišová, E., Kunová, S., Žiarovská, J., Kluz, M., Hanus, P., Puchalski, C., Kántor, A. 2018. Bacteria and yeasts isolated from different grape varieties. Potravinarstvo Slovak Journal of Food Sciences, vol. 12, 2018, no. 1, p. 108-115. https://doi.org/10.5219/878

Kántor, A., Petrová, J., Hutková, J., Kačániová, M. 2016. Yeast diversity in new, still fermenting wine „federweisser“. Potravinarstvo Slovak Journal of Food Sciences, vol. 10, no. 1, p. 120-125. https://doi.org/10.5219/547

Kántor, A., Kačániová, M., Kluz, M. 2015. Natural microflora of wine grape berries. Journal of Microbiology, Biotechnology and Food Sciences, vol. 4, no. 1, p. 32-36. https://doi.org/10.15414/jmbfs.2015.4.special1.32-36

Kántor, A., Mareček, J., Ivanišová, E., Terentjeva, M., Kačániová, M. 2017. Microorganisms of grape berries. Proceedings of the Latvian Academy of Sciences. Section B. Natural, Exact, and Applied Sciences, vol. 71, no. 6, p. 502508. https://doi.org/10.1515/prolas-2017-0087
Knight, S., Klaere, S., Fedrizzi, B., Goddard., M. R. 2015. Regional microbial signatures positively correlate with differential wine phenotypes: evidence for a microbial aspect to terroir. Scientific Reports, vol. 5, p. 14233. https://doi.org/10.1038/srep14233

Kunová, S., Kántor, A., Terentjeva, M., Felsöciová, S., Ivanišová, E., Kluz, M., Hanus, P., Puchalski, C., Kádasi Horáková, M., Kačániová, M. 2018. Microscopic fungi isolated from different slovak grape varieties. Potravinarstvo Slovak Journal of Food Sciences, vol. 12, no. 1, 2018, p. 438-443. https://doi.org/10.5219/893

Pinto, C., Pinho, D., Cardoso, R., Custódio, V., Fernandes, J., Sousa, S., Pinheiro, M., Egas, C., Gomes, A. C. 2015. Wine fermentation microbiome: a landscape from different Portuguese wine appellations. Frontiers in Microbiology, vol. 6, p. 905. https://doi.org/10.3389/fmicb.2015.00905

Pitt, J.I., Hocking, D. A. 2009. Fungi and Food Spoilage. $3^{\text {rd }}$ ed., Springer, 519 p. ISBN 978-0-387-92207-2.

Renouf, V., Claisse, O., Lonvaud-Funel, A. 2007. Inventory and monitoring of wine microbial consortia. Applied Microbiology and Biotechnology, vol. 75, p. 149-164. https://doi.org/10.1007/s00253-006-0798-3

Samson, R. A., Frisvad, J. C. 2004. Polyphasic taxonomy of Penicillium subgenus Penicillium: new taxonomic schemes and mycotoxins and other extrolites. Utrecht, Netherlands : Centraalbureau voor Schimmelcultures. 260 p. ISBN: 9070351-53-6.

Samson, R. A., Hoekstra, E. S., Frisvad, J. C., Filtenborg, O. 2002. Introduction to food-and airborne fungi. $6^{\text {th }}$ ed. Utrecht, Netherland : Centraalbureau voor Schimmelcultures. 389 p. ISBN 90-70351-42-0.

SHMU 2018. Climate reporting (Klimatologické spravodajstvo). Available at: http://www.shmu.sk/sk/?page=1\&id=klimat_operativneudaje 1\&identif $=11858 \&$ rok $=2018 \&$ sub $=1$

Taylor, M. W., Tsai, P., Anfang, N., Ross, H. A., Goddard, M. R. 2014. Pyrosequencing reveals regional differences in fruit-associated fungal communities. Environmental Microbiology, vol. $\quad 16, \quad$ p. $\quad 2848-2858$. https://doi.org/10.1111/1462-2920.12456

\section{Acknowledgments:}

This work has been supported by the grant of the European Union project no. 26220220180: Building Research Centre "AgroBioTech" and the grant of Slovak Research and Development Agency No. VEGA 1/0411/17.

\section{Contact address:}

*Miroslava Kačániová, Slovak University of Agriculture, Faculty of Biotechnology and Food Sciences, Department of Microbiology, Tr. A. Hlinku 2, 949 76, Nitra, Slovakia, Faculty of Biology and Agriculture, University of Rzeszow, Department of Bioenergy Technology and Food Analysis, Zelwerowicza St. 4, 35-601 Rzeszow, Poland, Tel.: +421376414494, E-mail: miroslava.kacaniova@gmail.sk

Simona Kunová, Slovak University of Agriculture, Faculty of Biotechnology and Food Sciences, Department of Food Hygiene and Safety, Tr. A. Hlinku 2, 94976 Nitra, Slovakia, Tel.: +421376415907, E-mail: simona.kunova@uniag.sk

Soňa Felsöciová, Slovak University of Agriculture, Faculty of Biotechnology and Food Sciences, Department of Microbiology, Tr. A. Hlinku 2, 94976 Nitra, Slovakia, Tel.: +421376415813, E-mail: sona.felsociova@uniag.sk

Eva Ivanišová, Slovak University of Agriculture, Faculty of Biotechnology and Food Sciences, Department of Plant products storage and processing, Tr. A. Hlinku 2, 94976 Nitra 


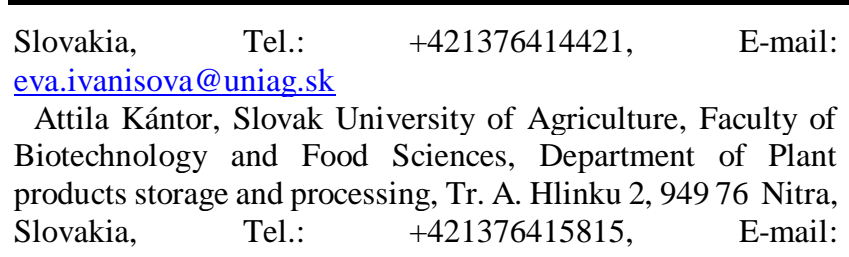
Slovakia, Tel.:
attila.kantor@uniag.sk

Czeslaw Puchalski, Faculty of Biology and Agriculture, University of Rzeszow, Department of Bioenergy Technology and Food Analysis, Zelwerowicza St. 4, 35-601 Rzeszow,
Poland, $\quad$ Tel.: $\quad+48178721000$,

E-mail: cpuchal@univ.rzeszow.pl

Margarita Terentjeva, Latvia University of Life Sciences and Technologies, Faculty of Veterinary Medicine, Institute of Food and Environmental Hygiene, K. Helmaña iela 8, LV3004, Jelgava, Latvia, Tel.: +37163024663, E-mail: margarita.terentjeva@1lu.lv

Corresponding author: * 